\title{
Perception of Web Users on the Effectiveness of Search Engine Marketing and Search Engine Optimization in the Era of Digitalization
}

\author{
S. Manikandan
}

\begin{abstract}
The Digital era has revamped many sectors and industries, information sharing is considered as the most important aspect any business now, any industry have not been spared from the technological growth, digital world have given an opportunity to go on business of your product and services online. The attitude of the consumers and their behavior has seen considerable change; the business has to cater the needs of their customer's. The product or services can be reached the end users much easier through virtual digital marketing cutting across the geographical and political boundaries. The websites created by the business has to be on the internet, not only on the net but have to land on the prime pages of the Search Engines, the marketers have to strive for ranking their webs on the top hit rank in order to be in the market. This article attempts to study the Search Engine Marketing (SEM) and to improvise on the strategies to remain on top by carrying out Search Engine Optimization and to adopt Search Engine Marketing Strategies (SMES) on a more effective way and also provides suggestions based on the empirical facts.
\end{abstract}

Keywords : Digitalization, digitized markets, SEM (Search Engine Marketing), SEO (Search Engine Optimization) and SEMS (Search Engine Marketing Strategies).

\section{INTRODUCTION}

In the Digitalized era, the marketing in a traditional form has been invisibly replaced, the prenominal presentation of the original markets have been completely changed. The virtual form has been over taken the contemporary form of marketing. The pace in which the advancement of technology is progressing is unimaginable and even uncontrollable. The essence of Digitization is present in every walk of life of the society. The economy is digitalized; the economic activities are facilitated using technology in specific the information sharing. The state of the economic transaction are so, if the digitalized technology breaks the survival of the society itself is big question to be answered. A digital dependent society is the order of the day. This ear of Digitalization is moving in direction toward Cen percent functionality on digital economy. This pace of rapid advancement has never been seen in any other contemporary eras.

The economy has explored new changes and new form of channelings and has encountered many troubleshooting

Revised Manuscript Received on December 05, 2019.

* Correspondence Author

Dr. S. Manikandan *, Associate Professor \& Research Supervisor, PG \& Research Department of Commerce, Guru Nanak College, Chennai which are been resolved using the rapidly increasing innovative technological advancement. The participants of the economic transactions in buying and selling of products and services across industries have seen a tremendous change in their attitude and behavioral aspect, the feel of new digitalized technology has given a new experience to the customers as well the industry. This has customized the pattern of marketing and its idea and design, the face look of the marketing has seen a paradigm change in the reconstruction of major economic activity including marketing. This has forced the industry to shift towards a digitized market to cater the needs of consumers who live in a digital dependent society. This from of marketing can be termed as online marketing or internet marketing, market has transformed substantially in the recent past. The market has gone global visible through the world crossing the political boundaries of countries. This growth in marketing is on due to the exploration and hasty usage of internet, which ensures fast and flexible buying and selling with cost efficient with a global reach. This has been a creditable boon to the business the impact has forced the industries to go digitized looking forward to new technology based markets.

\section{Interactive and Virtual Global internet marketing}

The fading of traditional method of marketing has given way to a new path for an interactive and virtual format of exceptional global internet marketing, but leave away the uniqueness of traditional marketing like personal contact, zero bargaining, lack of touch and feel of products, make a real deal, physical exchange and so on and on but to encounter with doubts on privacy and worries on security. But however one should accept the fact that the impact created by online marketing is tremendous. The new sharing of information has exploited new marketing techniques and adapts new strategies in order to meet the consumers' needs and to satisfy them. Online marketing has induced the consumers' decision of purchase and a change in the purchasing habits or it can be in the other way that the consumers' behavior and attitude has made this change in the design of marketing converting into online marketing.

\section{Online marketing}

Online marketing has a spread on various forms by usage of internet such as blogs, chats, social media flat forms, mobile apps and other form of digital interface. 
The society has penetrated into mobile device by aggressive usage of mobile internet and slowly and steadily marching towards mobile digital culture with a personalized digital environment. This personalized digital cultural environment has deeply covered the minds of the users. This digital environment incorporated a new and suitable environment which specially complements each consumer separately but is designed in such a manner that the consumer can have multiple environments for different products and services, different environment for different brands. As these users are more specific and focused towards new dimension of taste and preference that could suit to larger consumers. The digital society consumers have multi personalized preferences under different situation, in such case the industry has been entrusted with a job of creating mass audiences and to have a regular consumers who access in digital media or online platform, building mass audiences by the marketers is considered as a capital investment.

Internet introduction in the economy has reconstructed and reshaped in various sectors epically in travel, medicines, health, banking, insurance, transport, hotel, tourism, education, fashion, durable goods, etc. in the era of digitalization these industries have the feel of the potential of marketing online their products and services its impact on the buying behavior of the consumers due to marketing online. It is to note that it has been mutual for both the consumers as well as the marketers to place their products and services online eliminating the political boundaries and for consumer's enormous volume of data on the product and service end.

This exploration of new information sharing has forced the marketers to imbibe various techniques to tailor the needs of marketing on web. The marketers have to work on these functionalities like name of the products, its brand, features, design, pricing, promos, reviews, delivery details, ratings, durability, quality, warranty and so on to build confidence in the minds of the consumers to make an impact in their decision on purchase. The consumer's have an outright availability on the brands of alternative, belonging to different products by different business houses. These has to be taken into account by the online marketers and reframe their displays using various techniques which will be able to create an impact on the consumers decision of the way of buying to be treated as an asset.

\section{SEM (Search Engine Marketing) and SEO (Search Engine Optimization)}

The next which marketer has to move on it the form or the Platform on which their products or services are to be placed on or generating a consumer accepted root through which the consumers can be reached, more significantly the path to reach them would have to be for informative, sharing, interactive, participative, triggering, stimulating online/offline judging etc. in establishing a rich content info, as internet marketing is process of trying to reach the products and services to the users of net through various forms one such through is $\mathrm{SE}$ (Search Engine), the most vital is that the web should hit the top part and primary page of any
Search Engine results which are termed as SERPS(Search Engine Result Pages). This process of putting on internet the products and services for promos leading to increase in the quantity of sales, such activities can be called as SEM (Search Engine Marketing). The job of marketers do not stop in SEM, but they have to see that their web appears in front and frequently among the web traffic these activity of making your web more visible and escalating the ranking of webs is generally called as SEO(Search Engine Optimization).

SEM (Search Engine Marketing) is marketing on net for the purpose of promoting the website in the Search Engine result page either by paying for it or otherwise at free of cost. SEM has become an effective way to develop any trade or business through online focused on the promotion of products or services ensuring that one's website is much visible in any search engines it is considered as a strategy for marketing.

SEO (Search Engine Optimization) is a part of SEM which includes all the activities to extemporize the visibility of the web and improving the rank in the search engine result page, the success of the SEO will be evident from the high rank websites appears prime and more frequently in the list of result, resulting in more traffic from the users of the SEs. SEO are also done by paid or can be organic, once it is a paid one the providers will allot space to advertise which can result in top rank for their one web. SEO ensures the escalation of quantum of web traffic by increasing visibility of the page along with quality.

SEM is includes SEO all activates such as web crawling, search for key words, moving from one page to another, creating indexing based on the keyword analysis, location of crawled page etc., helping in the visible structure of your search page along with varied info. SEM lands on the perfect page to make for converting into sales, SEO are sheet of contents and designed information with the relevant key words ranked based on search engines. SEM leads to predication of retunes in the form of improving return on investment for the business.

SEMS(Search Engine Marketing Strategies) can also be an ellipsis of SEM as it is the effective form of developing business and promoting products or services through online, strategies are framed to necessitate the users who are in the hunting mode for a particular product or service their information are provided to meet their requirements. This requirement of the hunter is sensed by the search engine and provides the best sources from which the targeted information could be obtained. SEMS has inculcated many activities to name it SEO, presenting web to directories, indexing it, listing by pay mode, appropriate text, social media marketing, SEM plans, targeting the users, addition of new and updated contents, appropriate keywords, link construction to blogs platforms, to other webs, which would escalate the ranking. 


\section{HISTORY OF SES}

In mid 90s new webs got created quite a number of sites starting to appear online in World Wide Web, the quantum and quick appearance of webs gave way for creation of search engines in order to facilitate the users with more information within fraction of second.

Initially it was required to type the address if a page completely or URL and the same send to crawl the page and finds the correct linked page, as these search engine providers developed their services in the form of business module to generate finance out of this, many engines like Open Text in 96, Goto in 98, google in 2000 and yahoo in 2003 were been under this category. This avenue has been consciously Google dominated and eventually Yahoo and Microsoft went on alliance offering a tough compete. This term SEM gained its popularity in the 2001 coined by Danny Sullivan.

\section{RESEARCH METHODOLOGY}

Primary data were collected from respondents using structured questioner, survey method were also used to make the respondents complete the questionnaires with multiple choice, Likert scale and open ended questions. The method of sampling used were non probability the researcher has selected the samples on the subjective judgment. The sample size was taken as 120 from different parts of Chennai city, which is the study area. The statistical tools used were one sample $t$ test and Chi square test for interpreting the data. The variables for analysis taken were: Length of Title page Length of description (Text), Primary keywords, Maps, Image tag, Link to be crawled, Page size (kb) and Loading time. These were tested using other factors relating to the attitudes based on Demographic variables of the respondents based on Text at expected level, Relevant information on the top page, No. of results appearing, time (in seconds) Taken to respond and Suggestions to Searches related.

Table-I: Demographic variable of the Respondents

\begin{tabular}{|l|c|c|}
\hline Demographic Variables & $\begin{array}{c}\text { No. of Respondents } \\
\mathbf{N}=\mathbf{1 2 0}\end{array}$ & Percentage \\
\hline Age: & 19 & \\
Below 25 years & 49 & 15.8 \\
25 years to 40 years & 34 & 40.8 \\
41 years to 60 years & 18 & 28.3 \\
Above 60 years & & 15.0 \\
\hline Gender: & 85 & 70.8 \\
Male & 35 & 29.2 \\
Female & 6 & \\
\hline Education: & 15 & 5.0 \\
SSLC & 18 & 12.5 \\
HSC & 34 & 28.3 \\
Under Graduation & 47 & 39.2 \\
\hline Post-Graduation & & \\
Professional & 85 & 70.8 \\
\hline Marital Status: & 35 & 29.2 \\
Married & & 13.3 \\
Unmarried & 16 & 21.7 \\
\hline Occupation: & 26 & 29.3 \\
Student & 28 & 12.5 \\
Salaried Person & 35 & 4.2 \\
Self-Employed & 15 & \\
Professional & 5 & \\
Others & & \\
\hline Income Level: & & \\
Below Rs.15000 & & \\
\hline
\end{tabular}

\begin{tabular}{|l|l|l|}
\hline Rs.15000 to Rs.30000 & 38 & 31.7 \\
Rs.30000to Rs. 45000 & 41 & 34.2 \\
Above Rs. 45000 & 36 & 30.0 \\
\hline
\end{tabular}

From the primary source of data in the Table no.1, it has been absorbed that 40.8 percent (49) of the total respondents are from the age group of $25-40$ years, the respondents from Gender 70.8 percent(85) and 29.2(35) are male and female respectively, the maximum 47 (39.2 percent) of the total have studied their professional and followed by 34(28.3 percent) with education of Post-Graduation, regards the Marital Status the high 85 (79.8 percent) are married and 35 (29.2 percent) belong to unmarried, $35(29.2$ percent) are professional and followed by 28(23.3 percent) are Self Employed in their Occupation and of the total respondents regards to Income level the maximum are from Rs.30000to Rs.45000 which are 34.2 percent(41) and next to it is Rs. 15000 to Rs. 30000 which is 31.7 percent(38).

Table-II: t-Test for Variables on SEM

\begin{tabular}{|l|c|c|c|c|}
\hline & N & Mean & $\begin{array}{c}\text { Std. } \\
\text { Deviation }\end{array}$ & $\begin{array}{c}\text { Std. } \\
\text { Error } \\
\text { Mean }\end{array}$ \\
\hline Length of Title page & 120 & 3.25 & 1.132 & .103 \\
\hline $\begin{array}{l}\text { Length of } \\
\text { description(Text) }\end{array}$ & 120 & 3.31 & 1.165 & .106 \\
\hline Primary keywords & 120 & 3.22 & 1.139 & .104 \\
\hline Maps & 120 & 3.21 & 1.194 & .109 \\
\hline Image tag & 120 & 3.33 & 1.101 & .101 \\
\hline Link to be crawled & 120 & 3.18 & 1.123 & .102 \\
\hline Page size (kb) & 120 & 3.29 & 1.118 & .102 \\
\hline Loading time & 120 & 3.17 & 1.072 & .098 \\
\hline
\end{tabular}

The above table-II explains regarding the opinion of the respondents on the factors that are available on the web page directed from the Search Engine and about the Search Engine Marketing the features posted by the business on their website. These qualities help the marketers to increase their sales. The marketers do believe that having required features would improve their website landing on the top pages of the Engines in turn make business out it. The mean values that are above 3 points out of the 5-point Likert Scale results, are higher level of education, income and occupation are the driving force and most influencing variables that will enable to make business successfully.

Table-III: Chi-Square Test for Expected Features of SEO

\begin{tabular}{|l|c|c|c|c|c|}
\hline & $\begin{array}{c}\text { Text at } \\
\text { expected } \\
\text { level }\end{array}$ & $\begin{array}{c}\text { Relevant } \\
\text { information } \\
\text { on the top } \\
\text { page }\end{array}$ & $\begin{array}{c}\text { No of } \\
\text { results } \\
\text { appearing }\end{array}$ & $\begin{array}{c}\text { Time } \\
\text { (in } \\
\text { seconds) } \\
\text { Taken to } \\
\text { respond }\end{array}$ & $\begin{array}{c}\text { Suggestion } \\
\text { to Searches } \\
\text { related }\end{array}$ \\
\hline Chi-Square & 23.583 & 34.167 & 44.833 & 39.667 & 31.417 \\
\hline Df & 4 & 4 & 4 & 4 & 4 \\
\hline
\end{tabular}




\begin{tabular}{|l|l|l|l|l|l|}
\hline $\begin{array}{l}\text { Asymp. } \\
\text { Sig. }\end{array}$ & .000 & .000 & .000 & .000 & .000 \\
\hline
\end{tabular}

$(0.0 \%)$ have expected frequencies less than 5 . The minimum expected cell frequency is 24.0 .

On the observation of the Table no. 2 and Table no.3, indicates that there is high level of awareness about the variables in Search Engines among the respondents, further the Chi - Square value also indicates there is significant difference in the respondent level of satisfaction for the reasons towards the Search Engine Optimization done by the Providers to the users, hence the assumption made in the form of hypothesis by the researcher is accepted at $5 \%$ level of significance. The respondents are satisfied regarding the functionality of the features provided on the web.

\section{SUGGESTIONS}

- The study suggests that keywords analysis tools have to be designed and these keywords have to frequently tested. Keyword research has to done by keeping in the thoughts your customers.

- Updating of web and have a pleasing web design is must and keep on adding new and fresh contents, new formats; related videos are to be displayed on your web.

- Incorporate articles relevant to your web, as far as it is needed providing link to those articles, have reviews on those articles along with interactive responses from the users.

- On a continuous feeds are to be updated, unwanted feeds to avoid and necessary feeds are to be available in all junctions.

- Monitoring of your business competitors web shall induce you to go for further modification or improvement, provide unique depictions that your counterpart has not provided.

- Have your information crisp and short not elaborate as one do not want to read hulking substances, probably highlight statistical data which typically attracts.

- Web can attract hunters only if they are creative and quality content that are needed for the present environment, take out which are outdated and expired this will create bad image of the business.

\section{CONCLUSION}

In this most trending era of digitalization the world has seen a enormous usage of technology especially in information sharing, the industry has taken advantage of this situation to outfit the needs of their consumers beyond physical boundaries, world is now as Nano as in its size, global village is expired term the world is much smaller than it. Web sites of an industry have been the face of any business, usage of smart phones by the society has a greater impact on the individual behavior in general and the buying behavior in particular. The world of apps and social media is playing an important role in promoting the products and services of any industry. Feeds are considered more important and the reliability of such feeds in the form of information helps the industry to sell their products or services as well the consumers on a hunt of certain products just brows with their key words, it happens to be the Search
Engine that popups with the requirement and smart enough to read the minds of the users to provide such platform on which can get introduced to the product or services. The marketers are vested with still more responsibility to escalate their industry in the prime pages to have the traffic of their products or services. This digital environment demands more and continuous focus on the content's quality and the design or the architecture of the web, so best use of SEMS will certainly provide a hassle free clicking environment to the browses by ensuring SEM and SEO are at its best can guarantee a beautiful market place of any business.

\section{REFERENCES}

1. Gupta \& Agrawal - (2016), A Review on Search Engine Optimization: Basics, International Journal of Hybrid Information Technology, Vol. IX, Issue V.

2. Arokia Terrance etal.- (2018), Importance of Search Engine Marketing in the Digital World, Proceeding of international conference on information Technology and Knowledge Management,

3. Samrat.K - (2011) Concept of Search Engine Optimization in Web Search Engine, IJAERS, Volume. I, Issue I.

4. George etal (2003) Society for Consumer Psychology Web-Based Chatting: Consumer Communication in Cyberspace, Journal of Consumer Psychology, Volume XIII.

5. Lidina Javed (2013) Online Marketing through Consumers: A Study of Effectiveness of Various Tools, British Journal of Marketing Studies Volume. I, No.4.

6. Soheila Bostanshirin (2014) Online Marketing Challenges and Opportunities, Proceedings of SOCIONIT International Conference on Social Sciences.

7. Rohit Kumar and Tausheef (2014) Internet Marketing Boon or Bane for Indian Exporters, IJRMP, Volume. III(1).

8. Davis (2006) Search Engine Optimization - Building Traffic and making money with SEO, O Reily Media, Inc, New York. Paul P (1996) -Marketing on the Internet, Journal of Consumer Marketing, Vol. XIII (iv).

\section{AUTHOR PROFILE}

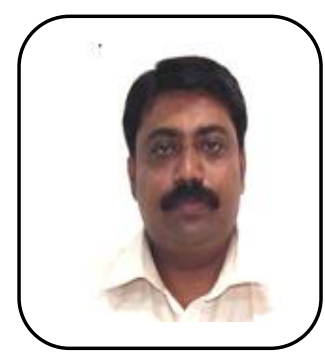

Dr. S. Manikandan, M.Com. M.Ed., M.Phil, Ph.D., qualified with SLET is an Associate Professor in the PG \& Research Department of Commerce., Guru Nanak College (Autonomous). He has 25 years of rich and varied experience in educating UG and PG students. He is a renowned Research Supervisor, Doctoral Committee Member and External Examiner of Ph.D. Viva Voce examinations and guiding 8 Ph.Dscholars and one candidate has been awarded. He is an exclusive author having more chronicles to his list namely Financial Accounting, Cost Accounting and Management Accounting which are so prevalent and widespread in the educational field. He is the Editor and Reviewer of many journals. He published more than 50 research articles in several leading Journals with High Impact Factor and presented papers in National and International Conferences. He is applauded for his many invited talks and lectures at various Colleges and Universities in National and International Conferences as a Resource Person and a Chair Person. He received 2 Honours and 3 Awards as the recognition of his valuable contribution in the field of education and research. He obtained and successfully completed a Major Project from UGC. He is the Co-Ordinator of IQAC, Vice President of Students' Council,Convener and Member in various committees of Guru Nanak College. 